\title{
The Role Of China In The Petro Political Map Of The 21st Century
}

Flory Anette Dieck-Assad, Instituto Tecnológico y de Estudios Superiores de Monterrey, Mexico

\begin{abstract}
This case presents the financial, political, and ethical dilemmas faced by an entrepreneur from London. His company, Shell Company of the Sudan Limited (Shell Sudan), is an indirectly wholly owned subsidiary of Royal Dutch Shell that no longer has operations in Sudan as of December 2008. Meanwhile, the Chinese National Petroleum Company (CNPC) has increased its exploitation of African oil in Darfur, Sudan. ${ }^{l}$ This paper introduces the reader to the new face that the black gold is giving to Chinese Foreign Trade Policy. The aim of the paper is to raise the debate about the world leadership that the emerging economy of China will develop during the XXI Century.
\end{abstract}

Keywords: Malacca's Strait; Terrorism; Ethics; Chinese Foreign Trade Policy; Oil, Global Financial Investments; United Nations; African Affairs

\section{INTRODUCTION}

$\mathrm{n}$ the arid African territory of Sudan's vast occidental border with Chad and the Central African Republic, a region called Darfur. This zone has recently turned into the international community spotlight after the
discovery of oilfields. The result was a ferocious armed conflict in order to get control over these new petroleum lands.

a region called Darfur. This zone has recently turned into the international community spotlight after the

Even under the devastating circumstances of the war, the brave and audacious Adriana Garza, a Mexican reporter from TV Azteca channel, defying the imminent dangers to which she might be exposed, decided to go deep into the conflict area and get near the victims in order to tell their stories. Hence, in search for the journalistic note for her T.V. program Hechos (Facts), Adriana found the opportunity to speak for those who were mostly affected by the conflict, those who have been confined to refugee camps in Darfur.

Sudan in Africa.
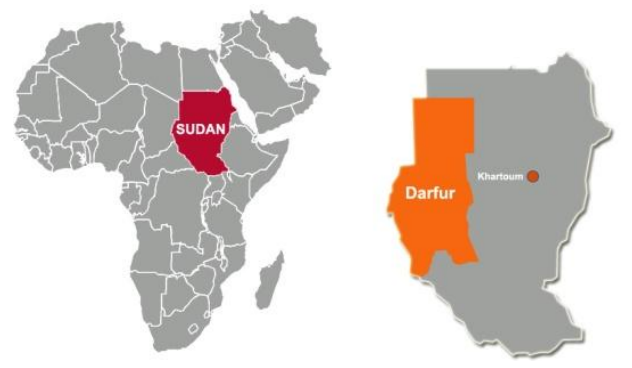

Darfur Region in Sudan.

\footnotetext{
${ }^{1}$ This Academic Case was written with the objective of serving as course discussion material where students can be able to learn about the ethical and economic global challenges of the petroleum world in the XXI Century. It can be used with the author's permission and requesting the Teaching Note for academic purposes. The case is based in the information provided by the organization where the case was researched. Some data has been altered to maintain confidentiality of the information.
} 
It was in one of these camps where the reporter met Thuraya, a young girl who was only 16 years old and despite the adverse circumstances she was facing, was still full of hope and dreamed about becoming a nurse. She was motivated by ideals beyond a childish humanitarian sense: - "I want to be a nurse to cure my friends that have been raped.", since she had experienced the same fate a few days before.

With tears in her eyes, Thuraya told a story that her friend Asma Mohamed had trusted her: - I went to the water well and three soldiers from my town approached me and aimed at me with their guns, one of them grabbed my legs and raped me. It was after listening many similar stories, that Thuraya decided that she should do something about it and help the girls get out from the hell they were living, by helping them get their freedom.

Unknowing the humanitarian crisis in Darfur, at the office located in the last floor of the luxurious Royal Dutch Shell Plc (known as Shell) Headquarters in central London, Sir Stephen Blunt smoked his Cuban cigar while listening to Peiong Ming, an executive from the China National Petroleum Corporation (CNPC) who presented him the different Chinese energy projects in Darfur, Sudan. A new oilfield had been discovered in Darfur and the CNPC was taking advantage of it with the objective to have another energy supplier for China.

By dusk, Mr. Blunt was back at his luxurious residence in the suburbs of London. During supper he shared with his family the conversation he had with Peiong Ming about the increased presence of the CNPC in Darfur, Sudan to exploit the "African black gold". This was a place his company had ceased operations since December 2008.

Suddenly the face of his son Stephen Blunt Jr, a brilliant student at Oxford University, turned pale, and he said: - Darfur?! -He asked- Are you not aware of what is happening in that region? Don't you see the news?

Even though his parents did not know where he got the information from, neither the reason why it came from a good source, Stephen Jr. told his father about the abuses that were being committed in Darfur. He told his parents how he was involved in a research two years ago, in the most objective manner, about the situation of the refugee camps in Darfur. He also told them how he invited his classmates to get informed about the African conflicts, and gave them phone numbers to offer help when required. He confessed to his parents that by using his own income and by organizing activities at a community service association at the university, he managed to mobilize a significant amount of people to generate ideas in order to evacuate the largest possible number of affected people in Darfur.

Stephen Blunt Jr. proudly commented to his parents that in this association they were united with the commitment of helping those in need, as a social work with groups that performed humanitarian activities in the world. His parents, with surprised expressions in their faces, remained silent with huge respect to the ideals of their son.

\section{BLOOD FOR PETROLEUM?}

Stephen Blunt Jr.'s words lit up an alert light within his father who decided to be informed about what was happening in Darfur. Very early next morning, Mr. Blunt, intrigued by the comments of his son, was already in his office in front of the computer surfing the web. He was very surprised to find headlines such as the following:

"Deadly Fighting Erupts in Darfur Camp"

"Darfur activists urge China to stop arming Sudan"

"Chinese oil firm under fire over alleged Darfur links"

"Tribal clashes leave 50 dead in Sudan"

"Local women aid Darfur refugees, take cookers to camps in Chad"

"Darfur-Fighting Story"

Still in shock, Stephen Blunt took a look around in hope of waking up from a bad dream, when the memory of his good friend Dr. Michael Jones, an expert researcher on the Middle East, suddenly came to his mind. Mr. Blunt and Dr. Michael Jones met each other a while ago in a convention dedicated to solve conflicts in the Middle East 
where one of the main objectives was to debate if oil was responsible for the conflicts in the Middle East, analyzing if that fact was a myth or reality.

Trying to rest in his couch, he took the newspaper and found an unexpected ad promoting a lecture of Dr. Michael Jones in the afternoon. - What pleasant coincidence, Mr. Blunt thought. The topic of the lecture would be about the future of Arabian petroleum: in matters of price, future availability, the seriousness and magnitude of the conflicts and the repercussions for the upcoming years.

Immediately he jumped from his couch and asked his secretary to cancel all his appointments for the day. He was absolutely convinced that he should go to the lecture with the objective to have an opportunity to chat with Dr. Michael Jones at the end of the event.

Indeed, he was there on time, and at the end of the event what had started as a business conversation, almost formal counseling, turned into an enjoyable chat with Dr. Jones about those subjects that were very interesting for Mr. Blunt. He knew that Dr. Jones was an important professor-researcher from Oxford University and that he was an expert on African affairs; so without losing any time Mr. Blunt asked him his opinion about the CNPC business in Darfur, a place where his company ceased operations since December 2008.

Dr. Michael Jones, now a bit more serious, since he understood his friend's concern, began to explain what was going on in Darfur.

- Indeed, as you have seen in the news, Darfur has been the scenario of several conflicts. Originally they were ethnical matters, which have caused thousands of deaths, but nowadays all of these events have become relevant in the international scenario due to the findings of important oilfields. Mr. Blunt, who listened carefully and wanted to obtain the most information possible, asked him, - And what are these ethnical conflicts?

- It is important to tell you that the conflict, contrary to what many people think, does not have a religious origin, but it is a product of an old rivalry between the Arabian nomads and the black agricultural population. These Arabian nomad groups, headed by the Janjawid, are protected by the government of Sudan, who provides them with armaments in order to carry out an "ethnical cleaning". To achieve this goal, they commit inhuman acts against the black population such as: destruction of thousands of villages, genocide, rapes, and plunders.

Horrified by what he was listening, Mr. Blunt replied: - But how is it possible that in our modern civilization, crimes such as genocide, thousands of displaced people, and raped women are still supported by the African government and the Janjawid? This is against Human Rights! It is inconceivable!

- It is indeed, and it is a reality, -- emphasized Dr. Jones--, but the worst of all is that this doesn't happen only in Darfur; crimes like these have always been committed in many other parts of the world.

Mr. Blunt, still hoping that not all of this was true and that the situation was not as serious as it seemed, replied: - But I read a couple of days ago, that United States is worried about this situation and is doing something about it. Journals say that US has put pressure on China, as a Permanent member of the United Nations (UN) Security Council, so that China does not continue protecting Sudan when another country demands sanctions against that Islamist Government.

- Indeed, --Dr. Jones said--, China protected Sudan in the United Nations Security Council, following its commercial strategy of "no intervention" with the sovereignty of the countries where China has business negotiations.

Dr. Jones continues with his explanation: - Even though we see violence in Africa, our world has also had an "awakening" towards the protection of the Human Rights of Darfur's inhabitants. However, we cannot deny that there is still an unsolved dilemma: the reasons of China's interest in Darfur. Let me continue, he said. 
- China is operating in Darfur due to China's lack of sufficient energy to supply its millions of inhabitants; this emerging economy sees Darfur as an important energy supplier, just as its neighbor country Chad. But before we judge the situation, we need to discover and understand the reasons behind the aggressive behavior of China in its intent to secure its energy supply.

- And do you think that someday a solution will be found? -asked Mr. Blunt sincerely concerned for the violent social situation that Africa was experiencing.

- It is very difficult to give you an answer, --honestly replied Dr. Michael Jones-- The conflict started in 2002 and it has worsened thanks to the discovery of oilfields. Even with the cooperation of several international actors it has not been possible for them to agree upon a fair negotiation for Darfur's inhabitants, yet. Oil is, indeed, the Apple of Discord.

After this conversation ended, Mr. Blunt looked for his son to express him his gratitude for his comments about Darfur. He invited his son to have lunch in a father-son meeting the next day, to debate the business strategies of China in order to understand the needs of this country. - This will be an excellent learning process for both of us, Mr. Blunt told his son who eagerly accepted the invitation.

\section{CHINESE FOREIGN TRADE STRATEGY}

In order to be ready to talk with his son, Mr. Blunt decided to study China in order to better understand its dilemmas. The current geopolitics of the world are outlined with black gold. China is an oil-importing country and definitely has to search for new suppliers that assure its access to natural resources.

The International Energy Agency (IEA) presented 'The Impact of the Financial and Economic Crisis on Global Energy Investment' on May 2009 and advised that because energy investments were experiencing a downward trend due to the global recession of 2009, energy prices could be triggered during the following years.

Indeed, IEA's report also stated that the global recession caused oil companies and alike investors to cancel or postpone investments of about $\$ 170$ billion dollars in 2009, which were equivalent to nearly 2 million oil barrels per day in future supply.

Moreover, a further 35 projects involving a future capacity of approximately 4.2 million additional oil barrels per day were postponed for at least 18 months while companies cut off their expenses.

The IEA's report draws attention to the increasing risk that the crude oil supply — high in 2009 due to the low consumption - could rapidly decline when the world economy recovers from recession.

What are the expectations of the IEA for 2012? Its main expectation is that the impact of the 2009 world recession on investments and oil capacity could be severe and generate higher oil prices. ${ }^{2}$

In this uncertain geopolitical environment, China, the world's second-largest oil consumer behind USA, is eager to have access to new oil suppliers, as part of China's strategy to secure the oil required for its economic development.

China imports about half of its oil requirements and these imports come from "vulnerable strategic routes", like the very narrow Strait of Malacca. Almost $80 \%$ of China's oil imports from Middle East and Africa are still transported through the Strait of Malacca, where the U.S. Marine is the official vigilant of this key chokepoint that links the Indian and Pacific Oceans.

This situation can explain one of the most important "fears" of China: the uncertainty of oil supply disruptions, or a possible threat of an oil embargo either from the USA (who watches out for this vulnerable

\footnotetext{
2 The International Energy Agency is financed by the 28 countries with highest oil consumption in the World.
} 
transport route) or from any other country or organization that could endanger the oil supply to the country. ${ }^{3}$

Mr. Blunt remembered the theories of the United States Navy flag officer: rear admiral, geostrategist, and historian, Alfred Thayer Mahan, who was famous for his vision of the strategic marine routes, as he stated: "those who control the seas control the world". ${ }^{4}$ Mahan sought to be provocative, triggering the debate from the perspective of economics and geography, since he was conscious of the importance of oceans as means of moving the goods required by international trade in this globalized world.

Where does China's fear of a disruption in its oil supply come from? - asked Mr. Blunt to himself. He thought that this was a right moment to go back in history to find out the reasons that caused the Second World War, as stated in his own words by Lieutenant Colonel Patrick H. Donovan, from the U.S. Air Force: "Throughout the summer and into the fall of 1941, Japanese negotiators and the USA were at loggerheads. The US led an oil embargo that would not be suspended until the Japanese stopped their military expansion. By September 1941, Japanese reserves had dropped to 50 million barrels, and their navy alone was burning 2,900 barrels of oil every hour. The Japanese had reached a crossroads. If they did nothing, they would be out of oil and options in less than two years. If they chose war, they were confident that they could win. That was Japan's best alternative and that is why the Japanese chose war". 5

Thus, USA imposed an oil-embargo to Japan in 1941 in response to Japan's brutal invasion to China. Japan answered with a military attack to Pearl Harbor on December 7 of 1941. - The historical memory of men keeps the wounds from those historical events-, thought Mr. Blunt.

Considering that China's oil demand will probably triple by 2030, it is obvious that this country is eager to diminish the risks for its oil supply and look for strategies that secure it, trying not to repeat the Japanese story.

As Peter Navarro clearly stated: "Today, oil remains the lifeblood of every modern economy, and considerable blood continues to be shed in the Middle East, Africa, and elsewhere to control or protect the vast network that brings this "black gold" from faraway places to the world's factories and transportation systems. What is disturbingly new about today's "blood for oil" wars is China's emerging and highly disruptive role".

In order to better understand the situation, Mr. Blunt made a geographical review, according to the map presented below.

China imports oil from Africa and the Middle East through the Strait of Malacca, a route that presents the following risks:

- $\quad$ The Strait of Malacca is the shortest and most efficient route to go from the Indian to the Pacific Ocean: this is the transportation route taken from the Middle East and Africa to reach the Asian markets.

- $\quad$ This is the route of transportation for almost $80 \%$ of China's oil imports.

- $\quad$ Blocking this Strait would effectively cut off China's oil-supply lifeline.

- This route could be closed by the U.S. Marine Force if there were any conflicts between China and Taiwan, Vietnam, Japan, Korea, or any other country.

- $\quad$ This route also presents a risk for pirate's attacks.

- The President of China, Hu Jintao, stated that China faces the "Dilemma of Malacca" for its high vulnerability of the oil supply coming from the Middle East and Africa. He said that his worst fear was to face a possible interruption.

- $\quad$ The traffic of oil tanks through the Strait of Malacca, whose littoral states are Malaysia, Indonesia, and Singapore, will grow from 10 million oil barrels per day in the year 2002 to 20 million oil barrels per day in

\footnotetext{
${ }^{3}$ The USA has a military base in the Province of Aceh, precisely in front of the Strait of Malacca.

${ }^{4}$ Ojeda Cárdenas, Juan N. La globalización y las Relaciones Económicas Internacionales, a la luz de la propuesta de Alfred Mahan. Vértice Universitario, Num. 44, Economía y Sociedad, oct-diciembre 2009.

${ }^{5}$ Navarro, Peter. The Coming China Wars, revised and expanded Edition, Financial Times Press, 2008, USA. p. 43.

${ }^{6}$ Navarro, Peter. The Coming China Wars, revised and expanded Edition, Financial Times Press, 2008, USA. p. 44.
} 
the year 2020.

- The Strait of Malacca is 1.7 miles wide creating a natural bottleneck, as well as potential for collisions, grounding, or oil spills. The International Chamber of Commerce has reported that piracy (theft and hijackings) is a constant threat to tankers in the Strait of Malacca. ${ }^{7}$

- $\quad$ According to Chinese specialists, USA has the military power to cut off China's oil imports with a devastating result: a paralysis of its economy for the lack of energy supply.

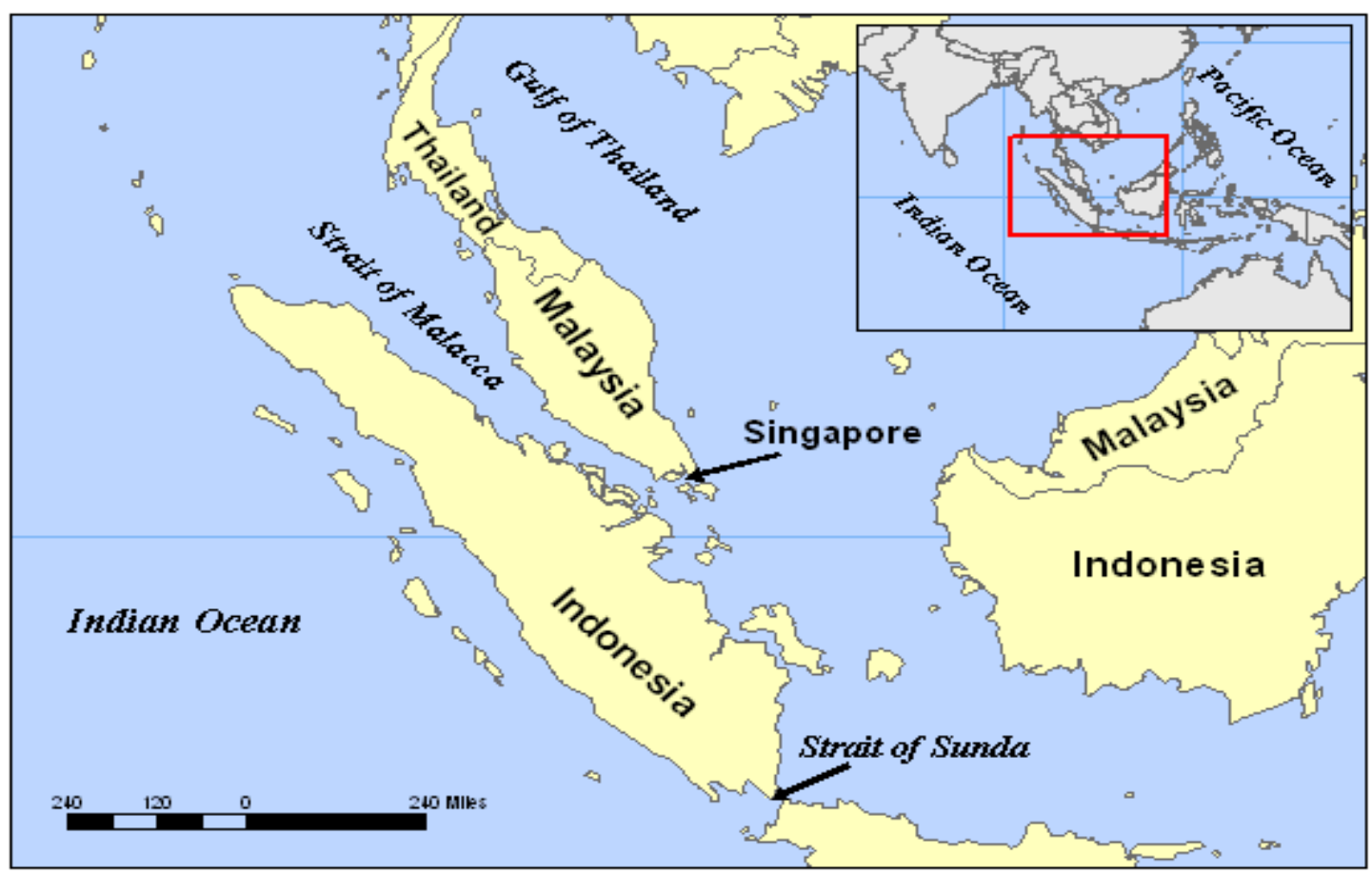

Map of the Strait of Malacca

China's fears have their own fundament. On April 26, 2004, Singapore Defense Minister Teo Chee Hean said: "What is in place today is not adequate, as it is an intensive and complex task to safeguard regional waters against maritime terrorism. The primary responsibility for the safety and security of the Strait of Malacca lies with the three littoral states; but, no single state has the resources to deal effectively with this threat". The USA proposal to intervene in the Strait of Malacca has been accepted so far in order to prevent any traffic of cargo related to weapons of mass destruction and terrorist networks. ${ }^{8}$

The USA initiative is based on the wish of all countries to participate in the global war against terrorism. The latest such proposal is for a "Regional Maritime Security Initiative" (RMSI) which is considered an intrinsic part of the ongoing "Proliferation Security Initiative" (PSI) project. The objective is the acceptance of interdicting "rogue ships", pirates, suspected terrorists, human traffickers, drug-peddlers, etc., on the high seas by the memberstates of the PSI, and to stop the illegal transfer of manufacturing equipment and components of weapons of mass destruction to other countries or terrorist networks.

Even though the PSI and the RMSI never really outlined a totally unilateral military initiative by Washington to safeguard the Strait, USA is the one that can supply high-speed vessels with Special Operations

\footnotetext{
${ }^{7}$ ICC (International Chamber of Commerce) is the voice of world business championing the global economy as a force for economic growth, job creation and prosperity. ICC activities cover a broad spectrum, from arbitration and dispute resolution to making the case for open trade and the market economy system, business self-regulation, fighting corruption or combating commercial crime. It was founded in 1919 in Paris. The organization's Paris-based international secretariat feeds business views into intergovernmental organizations on issues that directly affect business operations.

${ }^{8}$ Malacca Straits by P.S. Suryanarayana, May 24, 2004.
} 
Forces on them in order to conduct effective interdiction. The Strait of Malacca is a key chokepoint that could easily be shut down by the U.S. Navy in times of conflict.

Over 50,000 vessels transit the Strait of Malacca every year. If the Strait were to be blocked, nearly half of the world's fleet would be required to reroute around the Indonesian archipelago through the Lombok Strait, located between the islands of Bali and Lombok, or the Sunda Strait, located between Java and Sumatra. These new routes are more expensive. That is why China looks for alliances with other countries in order to build oil pipelines. These new investments are more profitable for China because they secure the direct supply of oil without going through the risky Strait of Malacca.

If it is considered that China and Japan have a dispute over the oil drilling in the East part of the China Sea, a latent Chinese invasion to Taiwan, and the existence of political issues with other Asiatic countries, the fear for a vulnerable energy security supply is not an unreasonable fear after all.

How has China sought to strategically address its oil-security fears? The answer is in the foreign trade strategy of China: adopting a "bilateral contracting approach" in which it seeks to lock down the physical supplies of oil-producing countries. The President of China Hu Jintao summarized his strategy with the following statement: "Just business, no political conditions". Thus, China is eager to negotiate the supply of oil without any involvement in politics, or in Human Rights, or in the sovereignty of those countries with whom China signs bilateral trade agreements, as is the case of Darfur.

Mr. Blunt discovered that there are several episodes in the history of China that show the scope of its strategy in bilateral trade. The most commented one was when China used its UN veto as a bargaining chip to secure access to the oil resources of Darfur in Sudan. China has this veto power because this country is a permanent member of the United Nations Security Council. Each permanent member has such veto power, and it only takes the veto of one member to block any type of UN sanctions or the use of UN peacekeeping troops. Due to China's intervention, the UN could not impose a sanction to Sudan for the genocide in Darfur, and China became the most important consumer of Sudan's oil as a reward for this protection. China also participates with $40 \%$ of the shares of a refinery that processes more than 300,000 barrels of oil per day and also an important oil pipeline from Sudan to the Red Sea. - Oh! This is what Dr. Michael Jones was trying to explain to me! -Mr. Blunt talked to himself.

Mr. Blunt remembered when the American Senator Richard Lugar and James Woolsey (former Director of the Central Intelligence Agency) clearly stated that energy is a key factor for the security of a country, as well as its economic welfare. A country which cannot secure the supply of energy to its people will probably use violence to get it.

Let's review another episode. This is the case of the brutal suppression of pro-democracy forces in Burma. ${ }^{9}$ Burma's military junta ruthlessly responded to peaceful protests that claimed a return to a democratic system by slaughtering thousands of Burmese citizens, killing a foreign journalist, and quite literally caging the Buddhist monks and nuns who helped lead the protests behind barbwire enclosures. China used its veto power to prevent any meaningful UN intervention.

Mr. Blunt questioned himself: -Why would China want to protect Burma's dictators? The answer that he found astonished him. China wanted to import the lion's share of Burma's natural gas reserves, which measure over half a trillion cubic meters. Far more strategically was China's plan to build a $\$ 2$ billion oil pipeline from Burma's coast on the Bay of Bengal to China's Yunnan Province. The Burma-China pipeline was a critical Project because it would allow China to take delivery of oil from the Middle East and Africa without passing through the very narrow Strait of Malacca. (The map below shows the strategic position of Burma for the construction of the pipeline that could supply oil to China from the Middle East and Africa).

\footnotetext{
${ }^{9}$ Navarro, Peter. The Coming China Wars, revised and expanded Edition, Financial Times Press, 2008, USA pp. 47-57.
} 


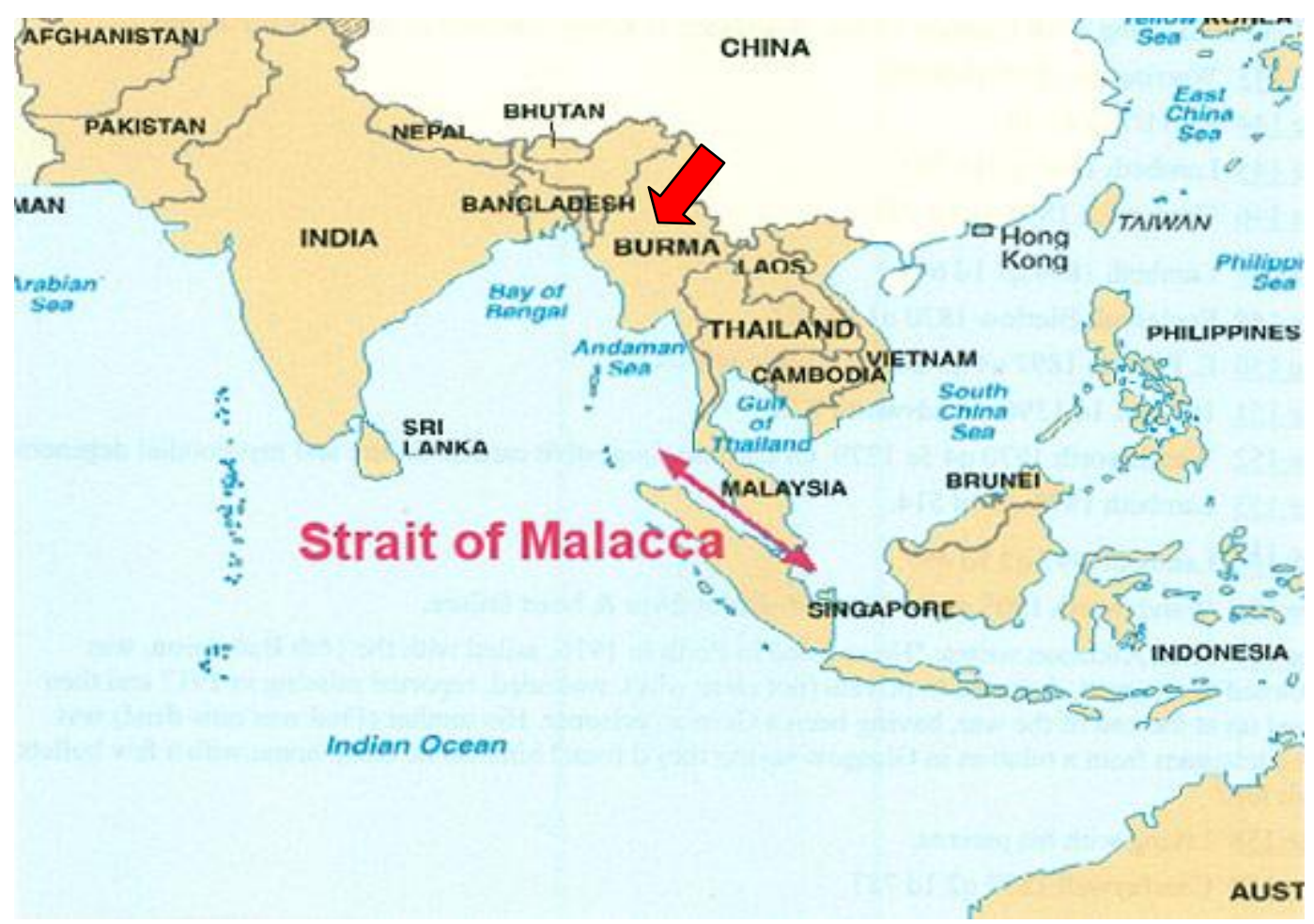

Strait of Malacca and the strategic position of Burma in the supply of oil to China.

China also signed a long term agreement in February 2009 with two Russian energy firms. China would lend $\$ 25$ billion American dollars in exchange for the supply of Russian oil. China was also using its financial health in order to have access to oil resources in the world.

China appeared in the world scene as an important player in the global industry of raw materials thanks to its relative financial strength during a period of recession for most of the economies in the World. The defense of the Chinese firms is that all their investments were based on entrepreneurial reasons, not on political reasons.

Thus, on February 17, 2009 the Development Bank of China signed a 20-year term agreement with the Russian public firm OAO Rosneft, the most important oil producer in Russia and with OAO Transneft, the manager of its oil pipelines. They would receive a loan in exchange for a secure supply of additional 15 million oil barrels (about 300,000 daily oil barrels, equivalent to $10 \%$ of the Chinese oil imports). Russia also offered an oil pipeline to China which would represent a secure and stable oil supply. The credit crisis and the decrease of global demand have impacted the oil industry in favor of the oil buyers. ${ }^{10}$

Another indicator of the growing influence of China in the petro-political map during this 2009 economic crisis was the fact that Brazil also knocked on China's door as a source of money. In fact, Brazil was looking for fresh resources in order to exploit the huge oil reserves that were discovered, in exchange for an oil supply to Chinese firms. This was the agreement: a loan of $\$ 10$ billion American dollars for 200,000 daily oil barrels. It was interesting to note that in March 2009, China became the largest trade partner of Brazil. ${ }^{11}$ It is a fact that the Chinese state banks were eager to give important loans in order to secure its oil supply.

\footnotetext{
${ }^{10}$ Winning, David, \& Oster, Shai \& Wilson, Alex. Russia Strike \$25 Billion Oil Pact In Third Deal in a Week, Beijing Moves to Lock Up Natural Resources at Bargain Prices to Fuel Its Growth, The Wall Street Journal, page A8, February 18, 2009.

${ }^{11}$ Lyons, John. Brazil Turns to China to Help Finance Oil Projects with Credit Markets Tight, President da Silva Hunts for Funding in Beijing, Offering His Hosts Secure Commodity Supplies, The Wall Street Journal, May 18, 2009.
} 
China is already heavily dependent on oil imports: importing more than $40 \%$ of its needs and its oil import dependence is projected to reach $60 \%$ by $2020 .{ }^{12}$ China's increase in its participation in the oil markets is the result of a desperate and furious strategy to secure the needed supply of oil for its economic growth. This strategy is causing a change in the geopolitical face of the world.

The path that China has decided to walk in is based on a "bilateral agreements" strategy. This is a path of "realism" where energy interests trump idealistic interests. If the world goes down this path, the world's geopolitical map will be redrawn along energy alliances. - In fact, --considered Mr. Blunt--, it is already happening. China in particular has made an outbreak of agreements to secure its energy interests with nations that the United States considers front lines in the war on terror.

It is important to pay attention to the changes of this new geopolitical environment where the Saudis, the Iranians, the Chinese, the Russians, and perhaps the Japanese, decide that good business relations are more important than abstract and intrusive political ideals. The development of the world's economic markets is driven by the "self-interest" of nations that may have very different political systems, but recognize that trading with each other is essential. They stay out of one another's internal affairs and enjoy the fruits of cheap gasoline and steady trade. $^{13}$

- Undoubtedly, --thought Mr. Blunt--, we cannot deny the facts that are painting the face of the geopolitical scenario of the world. Knowing historical facts can motivate a reflexive attitude, to stop our fast way of living and contemplate how "oil" is the new ink with which the world is writing a new history and painting the face of the new geopolitical scenario of the world during the XXI Century. It is important to realize the impact of Chinese trade strategies on the new petro-political map.

\section{FINANCES, ETHICS, AND POLITICS AT A CROSSROAD}

The following day, Mr. Blunt was ready to talk to his son. He was ready to have lunch with him in order to do a pleasant father-son talk about some dilemmas that he couldn't resolve by himself.

- I would like to discuss with you, my dear son, several matters for which I have not yet found satisfactory answers. With a questioning look, and with seriousness and respect, his son listened to his father who asked him the following questions:

- $\quad$ How should the Chinese population be judged, my dear son, in its evolution from Maoism towards a society of consumption that characterizes capitalist countries? ${ }^{14}$

- How would I act if I were the President of China and had to take decisions to solve the Dilemma of Malacca?

- How should the overwhelming Chinese commercial foreign policy be judged with its bilateral negotiation characteristics?

- How would China assure the energy supply that is required by a flourishing emerging economy?

- How could human values be defended and at the same time protect China's interests?

- $\quad$ Is our silence making us accomplices?

- How should China be judged in its role as a Permanent Member of the United Nations Security Council?

- How should the leadership shown by this Asian nation be judged?

- How could we evaluate the words of Mbuyi Kabunda?: "Human development, as defined by UNDP (United Nations Development Program), insists on social development centered in the people or in human capacities: basic needs, unemployment reduction, poverty and inequality eradication, education, healthiness, social services, sustainable and long lasting development..., meaning a collective humanistic and liberal ecological fundamentalism, versus the individualist economical and irresponsible

\footnotetext{
${ }^{12}$ Navarro, Peter. The Coming China Wars, revised and expanded Edition, Financial Times Press, 2008, USA, p. 45.

${ }_{14}^{13}$ Denning, Dan. The Japan-China Conflict: Old Mistrust, New Dependence. Whiskey and Gunpowder, April 2005.

${ }^{14}$ Maoism is a form of communism developed in China by Mao Zedong (Mao Tse-Tung).
} 


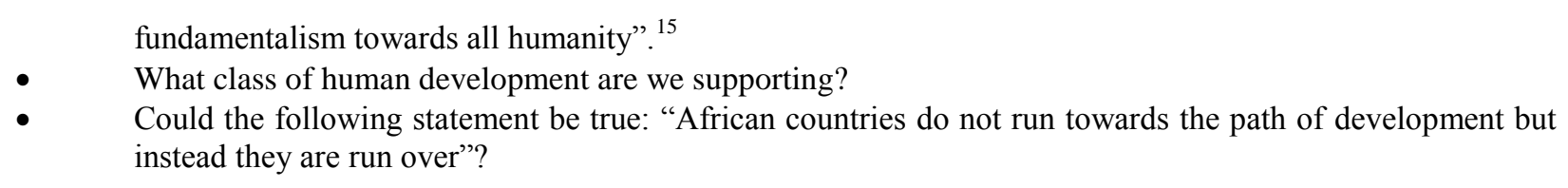

\section{AUTHOR INFORMATION}

Dr. Flory Anette Dieck-Assad, Instituto Tecnológico y de Estudios Superiores de Monterrey, Ph.D. in Finance from Tulane University (2003). McGraw-Hill published her first book "Financial Institutions" (2004). Invited lecturer in Mexico, Chile, U.S.A., Europe, and Canada, got the "Best Lecture Award" in 2004, 2008 and 2010. She has more than 70 publications in national/international magazines, reviews, and journals. She got the "Prize to Education and Research 2007 and 2010". Certified in the Case Method (2007), has written academic cases in energy \& ethics. Texas A\&M University Press published her second book titled: "Energy and Sustainable Development in Mexico" (2005), honored with the "National Romulo Garza Award for the Best Written Book" (2008).

\section{BIBLIOGRAPHY}

1. Bajaj, Vikas; Bradsher, Keith. 2009. Investors in Developing Markets See Optimism, The New York Times, June 4.

2. Denning, Dan. 2005. The Japan-China Conflict: Old Mistrust, New Dependence, Whiskey and Gunpowder, April.

3. French, Howard W. and Polgreen, Lydia. 2007. China, Filling a Void, Drills for Riches in Chad, The New York Times, August 13.

4. Goodman, Peter S. 2009. What Would Mao Drive? A Little Red ... Hummer, The New York Times, June 7.

5. International Energy Agency. 2009. The Impact of the Financial and Economic Crisis on Global Energy Investment, IEA Background paper for the G8 Energy Ministers' Meeting, 24-25 May.

6. Kabunda, Mbuyi. 2007. Dialogue for Peace Week: Africa and Peace, an interview with Dr. Mbuyi Kabunda Badi, Professor of Basel University at Switzerland, September 29.

7. Lyons, John. 2009. Brazil Turns to China to Help Finance Oil Projects with Credit Markets Tight, President da Silva Hunts for Funding in Beijing, Offering His Hosts Secure Commodity Supplies, The Wall Street Journal, May 18.

8. Navarro, Peter. 2008. The Coming China Wars, revised and expanded Edition, Financial Times Press, USA.

9. Ojeda Cárdenas, Juan N. 2009. La globalización y las Relaciones Económicas Internacionales, a la luz de la propuesta de Alfred Mahan, Vértice Universitario, Num. 44, Economía y Sociedad, octubre-diciembre.

10. Polgreen, Lydia, and French, Howard W. 2007. Entrepreneurs From China Flourish in Africa, The New York Times, August 18.

11. Polgreen, Lydia, and French, Howard W. 2007. China's Trade in Africa Carries a Price Tag. The New York Times, August 21.

12. Prieto, Javier. 2001. Piel de Líder, Editorial Panorama, México.

13. Amnesty International. 2004. Sudan: Darfur - attacks against civilians ongoing. http://web.amnesty.org/library/index/eslAFR540282004.

14. Suryanarayana, P.S. 2004. Malacca Straits, Ilankai Tamil Sangam, Association of Tamils of Sri Lanka in the USA, May 24.

15. Winning, David \& Oster, Shai \& Wilson, Alex. 2009. Russia Strike \$25 Billion Oil Pact in Third Deal in a Week, Beijing Moves to Lock up Natural Resources at Bargain Prices to Fuel Its Growth, The Wall Street Journal, page A8, February 18.

\footnotetext{
${ }^{15}$ Mbuyi Kabunda, born in the Democratic Republic of Congo (Africa), Ph.D. in Political Science, professor of International Relations at the Patricio Lumumba University (at Congo), member of the Institute for African Studies of the Autonomous University of Madrid (Spain), professor of the University of Basel at Switzerland, and actual President of SODEPAZ.
} 